Seniana 
Entrevista inédita 


\title{
JORGE DE SENA FALA A SEUS CONTEMPORÂNEOS - UMA ENTREVISTA INÉDITA
}

\author{
Sebastião Edson Macedo* \\ (apresentação e edição da entrevista)
}

1972 é um ano-chave para Jorge de Sena: em Maio sai Exorcismos, seu décimo livro de poemas; em Julho sai Poesia de 26 Séculos (de Arquíloco a Nietzsche); em fins de Setembro inicia a escrita do que é considerado seu "testamento poético»: «Sobre esta praia... (Oito meditações à beira do Pacífico)»; e no fim do mesmo ano publica a antologia 30 Anos de Poesia.

Também em 1972, Jorge de Sena realiza três grandes viagens largamente motivadas pelo IV centenário de publicação d'Os Lusíadas. No itinerário da terceira e última viagem está Moçambique. Sena chega à capital, a então Lourenço Marques, no dia 7 de Julho de 1972, permanecendo até $1 .^{\circ}$ de Agosto, quando segue para Luanda. É, sem dúvida, um momento marcante de sua vida, pois pisará no sítio em que Camões passou os últimos dois anos de exílio. Desta experiência, também entendida como um encontro com o poeta épico, resulta o poema «Camões na Ilha de Moçambique», lá escrito a 20 de Julho.

Durante sua estadia naquele país, Jorge de Sena concede uma entrevista à Rádio Moçambique, no dia 17 ou 18 de Julho, conduzida pelo jornalista Manuel Tomaz. Censurada pouco depois de sua gravação, esta entrevista nunca foi transmitida. Trata-se, na verdade, de 86 minutos de intensa reflexão crítica, histórica e literária de tudo aquilo que rodeou a vida e a obra de Jorge de Sena. Nas claras e caudalosas respostas, encontra-se toda a gama da conhecida erudição de Sena, articulada com um notável empenho pedagógico e um refinado senso de humor, que revelam o grande tecido de considerações estéticas, políticas e históricas, dentre outras, de que se fez o pensamento seniano.

Essa entrevista vem agora a público em primeira mão. Ela me foi apresentada, ainda em áudio, por Mécia de Sena ${ }^{1}$, em sua casa, em Santa Bárbara, quando lá estive, no primeiro trimestre de 2006, investigando no espólio ${ }^{2}$ de seu marido, graças a uma bolsa concedida pela Fundação Calouste Gulbenkian ${ }^{3}$. Nas páginas a seguir, apresento uma versão ligeiramente condensada, com a supressão de marcas próprias do discurso oral (como as frases bordão, frases suspensas, repetições literais, pequenas digressões, etc.), visando à maior fluidez na leitura. Em breve será publicada, na íntegra, tal como a transcrevi, na coletânea intitulada Entrevistas, Inquéritos, Cartas, já organizada pela viúva do escritor.

" Mestrando em Literatura Portuguesa na UFRJ; pesquisador júnior do Real Gabinete Português de Leitura do Rio de Janeiro; poeta, autor de Para Apascentar o Tamanho do Mundo (Rio de Janeiro: Oficina Raquel, 2006). 
Entrevista com Jorge de Sena, gravada a 17 ou 18 de Julho de 1972, pela Rádio Moçambique, em Lourenço Marques, conduzida por Manuel Tomaz [versão condensada]

Manuel Tomaz (MT) - Suponho que não vale a pena fazer qualquer espécie de apresentação ao público. Jorge de Sena é suficientemente conhecido e vai perdoar-nos o facto de não antecedermos de qualquer título o nome de Jorge de Sena. Vamos começar por perguntar ao poeta Jorge de Sena como chegou à poesia, se houve algum itinerário que o conduzisse a ela, nomeadamente um itinerário de leitura e de análise de outros poetas.

Jorge de Sena (JS) - [...] O que me aconteceu foi o seguinte: eu escrevi sempre, sem ter consciência disso, desde quando era criança, e por volta de, suponho eu, quando tinha 16 anos, comecei a escrever conscientemente do que escrevia. [...] Eu conhecia bastante, nesse tempo, os clássicos, [...] conhecia vários poetas estrangeiros das línguas que podia ler e estimava, e procurei ler mais, mas só depois é que eu comecei a conhecer os poetas modernos portugueses. Eu vivia tão fora do que fosse vida literária em Portugal que nem sabia que eles existiam. E aconteceu uma coisa muito curiosa: eu mostrava alguns dos meus primeiros poemas a colegas meus, primeiro de liceu, e depois de faculdade. E havia um par de amigos meus que tinham uma paciência, coitados, de ouvir aquilo tudo que eu mostrava. E uma das coisas que mais influência teve, por curioso que pareça, na maneira como eu me tornei independente na forma de escrever, foi a estreiteza de um dos meus colegas, que tinha a convicção de ser um dos homens mais inteligentes do mundo (sempre teve, coitado), e era um homem muito inteligente, realmente, mas que não entendia e que não conhecia nada de poesia moderna, e quis constantemente insistir em que aquilo tudo que eu escrevia não era poesia, nada daquilo era poesia, nada daquilo eram versos, nada daquilo tinha regularidade nenhuma, era uma coisa perfeitamente inclassificável. E foi, talvez por uma espécie de oposição ou reacção contra aquela atitude dele tão rígida, e de outras assim, que eu fiquei um poeta moderno sem me dar conta. Quando depois eu comecei a ler mais poesia moderna, muito admirado verifiquei que eu era um poeta moderno e não sabia.

MT - Ora, a poesia portuguesa, desde que Jorge de Sena começon a escrever, passou por vários caminhos, sofreu várias influências, e falou-se de várias correntes, ou existiram de facto várias correntes na poesia portuguesa. Jorge de Sena alguma vez sentiu-se incluído em algumas dessas correntes? 
JS - [...] Eu senti-me sempre incluído em diversas correntes. As correntes é que nunca me consideraram incluído nelas. [...] Estando eu a par do que se passava e sendo eu muito curioso de conhecer literatura, eu ia sabendo do que se passava nas outras literaturas e não estava, portanto, a descobrir a pólvora. [...] Por exemplo, eu creio que fui neo-realista, eu creio que fui surrealista, etc. ao mesmo tempo, ou antes, das pessoas que apareceram depois com os «ismos». Quer dizer: eu fui neo-realista quando conheci os neo-realistas, juntamente com eles. [...] Quando apareceram os Cadernos de Poesia (que primeiro foram organizados, como se sabe, por José Blanc de Portugal, Rui Cinatti e Tomás Kim...) [...] comecei a colaborar com eles - atitude, digamos, de vários dos neo-realistas, que o neo-realismo estava ainda a aparecer nessa altura, as obras ainda estavam por vir... O que havia eram as polêmicas, em grande parte como já costumava acontecer com os movimentos literários... E acontece que muitos desses neo-realistas eram nossos amigos pessoais (e continuaram a ser, como ainda são hoje), outros não eram, e, de uma maneira geral, catalogaram Cadernos de Poesia como sendo uma coisa que era o contrário deles. Mas os Cadernos de Poesia não eram o contrário deles, nem desde a primeira hora, até porque... as pessoas habitualmente ignoram, ou não sabem, ou nunca viram uma coleção dos Cadernos de Poesia, que é hoje uma coisa muito rara. [...] Toda a gente, de todas as cores (menos para um certo lado), todas colaboraram nos Cadernos de Poesia, e todas foram convidadas a colaborar nos Cadernos de Poesia e colaboraram neles, o que prova evidentemente que os Cadernos de Poesia não eram contra eles, senão tinham-nos excluído. Mas fazia parte, evidentemente, do mito (e há sempre os mitos polémicos em todas as coisas), de que as pessoas eram contra aquilo [...] E houve sempre outra coisa que nunca se entendeu, e que eu desejaria explicar: em Portugal é muito difícil, e sempre foi - e isso vem dos próprios defeitos da maneira de como a literatura é ensinada tradicionalmente - que as pessoas não sejam todas arrumadas numa prateleira, com uma ficha de catálogo, com um rótulo de um «ismo», de um isto ou daquilo ou daquilo outro, e, quando as pessoas não acertam numa coisa destas, estamos todos perdidos, porque os historiadores literários estão habituados a arrumar tudo segundo o catálogo e quando encontram uma pessoa em quem não podem pôr um rótulo simples, deixam-nos ficar no fundo da página, não é? E é o que costuma acontecer. E aconteceu connosco, com todos nós. Uma das coisas mais curiosas, por exemplo, é falar-se assim do «grupo» dos Cadernos de Poesia como se os Cadernos de Poesia tivessem sido um grupo. Os Cadernos de Poesia não foram um grupo; foram uma série de pessoas que fundaram uma revista com a intenção de que a qualidade poética, dentro de certos limites de exigência de consciência do mundo, fosse preservada, numa altura em que, de um lado, nós tínhamos a presença, os homens da presença, a gritar pelo documento humano, etc., etc. (e nunca diziam à gente como é que as pessoas escreviam fosse o que fosse) ou, do outro lado, tínhamos outros sujeitos a exigir que as pessoas 
se comprometessem aqui, ali e acolá. E todos a escreverem da mesma maneira, como os presencistas escreviam, e os presencistas e eles todos a escreverem como se escrevia antes de existir o Fernando Pessoa, não é? E esse é um dos raros segredos que a Crítica Literária não costuma sublinhar e é assim. E a atitude que nós assumimos coletivamente não foi a de um movimento. Foi, digamos, a de reagir, não contra as idéias, mas contra o facto de, no meio daquilo tudo, as pessoas se esquecerem de que a poesia se faz com palavras, a poesia se faz com expressão poética, a poesia se cria como um objecto estético, e não são necessariamente as idéias, ou as boas intenções, ou o documento humano, que faz seja o que for um objecto estético: é a própria arte com que as coisas são feitas.

MT - [...] Ainda há pouco tempo eu ouvi alguém, aliás na rádio, a referir-se ao que deve ser a poesia, frisando até, ou enunciando até certas normas, significando uma função social da poesia e a necessidade daquilo que os ingleses poderiam chamar um commitment ou os franceses um engagement. Qual é a posição do Jorge de Sena em relação a estes aspectos?

JS - Bem, eu acho que eu fui sempre, nesse sentido, um poeta engagé, ou se quiser um poeta commited. A única coisa que eu nunca fui, não sou e creio que agora já é tarde para ser é estar commited ou engagé a qualquer programa que me seja imposto por alguém. Eu sempre estive commited ou engagé às idéias que me impus, ou que eu aceitei eu mesmo. Quer dizer que eu nunca aceitei quaisquer programas partidários de qualquer espécie. Eu nunca pertenci a nenhum partido político, não pertenço e creio que nunca pertencerei... Da mesma forma que nunca pertenci a secções de futebol, a clubes de classe, a outras coisas; que sempre fui a pessoa menos associativa do mundo, porque acho que associação, nesse sentido, é o oposto da coisa que mais estimo, que é a convivência humana. Eu acho que conviver é muito mais importante do que a gente associar-se para comer bacalhau, ou a gente associar-se para celebrar o aniversário do Infante D. Henrique, ou a gente associar-se para salvar o universo, inclusivamente, porque há numerosas formas de salvar o universo, o que faz que todas juntas não cheguem para isso.

MT - Poeta português, e não apenas por linguagem, Jorge de Sena não vive em Portugal. E como, portanto, pode assumir, longe, a realidade [literária] portuguesa?

$[\ldots]$

JS - [...] Quando nós estamos de longe, temos pelo menos uma possibilidade, que é escapar àquele problema que sempre existe de, no meio da floresta, não se ver floresta por causa das árvores. E também aos erros de perspectiva, que fazem a gente julgar que uma árvore pequenina que está ao pé de nós é muito grande, 
e que uma árvore muito grande que está longe de nós é muito pequenina. E é exactamente isso: quando a gente está de longe vê-se melhor, corrigem-se melhor as coisas. Além do mais, eu penso que [...] ninguém tem a obrigação de ser o registro civil de tudo que se publica num país. A gente tem sempre tempo de esperar algum tempo, de saber quem é que se afunda e desaparece, quem é que fica. $\mathrm{E}$ aqueles que ficam a gente vai ler depois. Não há necessidade de ler todas as semanas tudo o que se publica. Até porque eu acho [...] que todas as literaturas normalmente são feitas de obras notáveis e de obras relativamente medíocres. E se a gente passar a vir todas as semanas a ler $80 \%$ de porcarias e $20 \%$ de obras boas, a gente acaba por medir as coisas boas pelo nível da porcaria, não é?

MT - Pois, nós temos que Jorge de Sena é também um crítico [...]. A Literatura Portuguesa Contemporânea [...] tem sofrido, uma certa evolução, e têm aparecido certos autores novos, com determinadas características e com alguma coisa para dizer em relação à própria realidade portuguesa. Qual é a opinião do Jorge de Sena sobre o momento atual da Literatura Portuguesa?

JS - É uma pergunta muito difícil de responder. [...] Primeiro de tudo, eu creio que, salvo em raros momentos excepcionais, o grande drama da Literatura Portuguesa - e é, até certo ponto, a teoria que tenho dela - foi sempre um grande afastamento da realidade concreta. E uma grande falta de experiência da realidade concreta, e que resulta das próprias estruturas sociais do nosso país. Acontece [...] que, de um modo geral, as pessoas, quando se tornam escritores, imediatamente, ou automaticamente, do ponto de vista social, deixam de ser povo. E quando deixam de ser povo, automaticamente deixam de saber como é que o povo fala e vive. Daí resulta grande parte do artificialismo que mesmo o maior realismo português usualmente tem. Vem de as pessoas realmente terem perdido o contacto com a realidade social imediata, para passarem a vê-la sob o prisma dos níveis oligárquicos de que passaram a fazer parte. $\mathrm{E}$ isto aplica-se a toda a gente, a todas as cores e feitios [...]. Só os grandes realmente, os muito grandes, são os que conseguiram ultrapassar esse drama. Mesmo assim, não exactamente no sentido em que, por vezes, se aponta que eles o fizeram. Quando, por exemplo, se aponta o populismo extremo de Fernão Lopes, as pessoas esquecem-se que Fernão Lopes é precisamente o cronista, não apenas daquela revolução burguesa em que tanto se insiste, de 1383, triunfante, mas da contra-revolução meio aristocrática que se aproveitou da revolução popular e burguesa para conquistar o poder. Quando as pessoas falam nessas coisas, dá-me a impressão de que nunca leram realmente Fernão Lopes. E se esquecem, por exemplo, de que a primeira parte da Crónica de D. João I é dedicada inteiramente só ao período de 1383-1385, que ele conta com uma minúcia extraordinária. Mas ele conta também [...] como as pessoas que fizeram esse putsch - porque, realmente, a revolução de 
1383 foi, numa grande agitação nacional, um putsch lisboeta - [...] manobraram totalmente a opinião pública, usaram o povo para os seus próprios fins. Isso está perfeitamente claro na narrativa de Fernão Lopes. E precisamente vale a comparar [...] com os grandes historiadores europeus seus contemporâneos, pelo facto de ser, ao contrário do que sucede com eles, um homem, um cronista que tem uma visão e uma compreensão social da História que os seus contemporâneos não têm. E a razão é muito simples: [...] porque as pessoas geralmente ignoram a História Comparada; [...] ignoram que, daquelas revoluções todas que agitaram a Europa nos fins do século XIV - que não foram exclusivo português: fenómenos semelhantes varreram a Europa no fim do século XIV - a única que triunfou, por estar misturada com problemas de independência nacional, foi a portuguesa. As outras perderam todas. E foi precisamente isso que colocou, nesse momento, Portugal, em relação às outras nações da Europa, numa posição internacional diferente daquela que os outros países tinham. Ora, o Fernão Lopes é o cronista deste triunfo. E ele distingue perfeitamente o que seja a aristocracia que sobe ao poder, em substituição da outra, que tinha aderido a Castela; mas, ao mesmo tempo, separa perfeitamente esses grupos de poder [...], do povo, cuja vontade de independência, cujo patriotismo, etc. é totalmente manobrado. Eu chamo a atenção das pessoas para irem ler nas crónicas de Fernão Lopes a passagem que se refere exactamente ao assassínio do Conde Andeiro, e como é que toda aquela coisa inteiramente manobrada propôs sair para a rua rebelar-se conta a pobre da D. Leonor Teles, que, se calhar, era até uma senhora muito simpática, que nós todos hoje vemos pelo prisma do Fernão Lopes, que tinha todo o interesse em apresentá-la como uma sujeita horrível, visto que ele era o cronista da dinastia triunfante. E tudo aquilo foi manobrado para D. João I saltar ao poder. [...] Mais adiante, ele transcreve o «conto» que se passou nas Cortes, que levaram D. João I ao trono: como essas Cortes foram extremamente populares, sem dúvida, mas inteiramente fabricadas. São umas Cortes em que toda a gente que não era partidária de D. João I não conseguiu entrar à porta. Ficaram todos na rua, e, de certo, uns quantos senhores que eram partidários dos filhos de D. Inês de Castro, aos quais filhos D. João I escreveu cartas dizendo que ele não se considerava Rei de Portugal. Quer dizer: o que era preciso era salvar Portugal primeiro, e depois se ia ver a quem é que o trono pertencia. Mas, entretanto, o João das Regras, nas Cortes de Coimbra, fez aquele famoso sermão compridíssimo, em que provava que toda a gente era ilegítima, ninguém tinha o direito a subir ao trono de Portugal, e que o único rei legítimo, perfeitamente legítimo, era o mais ilegítimo deles todos, que era exactamente D. João I, o que, sem dúvida, é uma tremenda exposição de técnica revolucionária, mas talvez não seja exactamente aquilo que as pessoas têm dito que é. O mesmo sucede [...] com Gil Vicente, de cujo populismo se fala tanto, esquecendo-se a gente de que Gil Vicente escreve para a Corte, onde os seus autos são representados, e onde os nobres da Corte se riem 
com bonomia e simpatia daqueles tipos cómicos populares que Gil Vicente lhes apresenta. Não era propriamente o povo quem estava a rir daqueles tipos. É possível que depois as peças fossem representadas aqui e ali. Nós temos algumas notícias disso. E que as pessoas se divertissem muito com aquilo. Mas quem se divertiu primeiro à custa do povo foram os nobres da corte, de D. Manuel I e de D. João III. [...] O que eu quero apontar com estes exemplos não é dizer que esses homens não tiveram uma grande consciência da realidade, como grandes escritores que eram. Simplesmente não são exactamente aquilo que certa demagogia superficial tem feito deles.

MT - Voltando à Literatura Contemporânea [...]. Quais os grandes momentos, ou os grandes acontecimentos, as grandes correntes que terão tido importância para a Literatura Portuguesa?

JS - [...] Para se compreender o que realmente se passou durante estas décadas, é precisamente ter-se dado, ou as pessoas terem dado a si mesmas, ou terem feito por dar, mais importância aos movimentos do que às obras. $\mathrm{E}$ as pessoas insistem muito em numerosos «ismos», e o que importa é a gente distinguir a importância histórica na Literatura, e para a Cultura, que certos movimentos poderão ter tido, daquilo que realmente se fez, não só como qualidade em si, mas até mesmo como correspondência em relação aos princípios proclamados. A crítica tem uma grande tendência para acreditar nas proclamações dos escritores sem verificar se as proclamações acertam com as obras e vice-versa. E, na realidade, uma das funções da crítica não é apenas acreditar nisso. É verificar se essas coisas são verdades. Mas a nossa crítica está tão ocupada em verificar se as pessoas cabem na bitola ou não cabem na bitola, que não tem tempo para verificar essas coisas.

MT - Jorge de Sena escreveu uma vez que, aparentemente, em Portugal, o escritor deveria ser dotado de uma certa dose de mediocridade para poder vencer. Não estou a fazer a transcrição textual dessa afirmação, mas disse que era quase um crime para um escritor, em Portugal, ser inteligente...

JS - Bem, isso vem, em grande parte, de que, em Portugal, ainda existe, e em grande parte desde o Romantismo, a idéia de que o escritor é assim um génio pela graça dos deuses, e que, quanto mais analfabeto seja, mais o génio sai puro. Acontece que quando um sujeito é analfabeto o que sai é analfabetismo, não pode sair outra coisa, porque não tem lá mais nada para dizer à gente. E mesmo que tenha, [...] ele não sabe como é que há-de dizer, e sai tudo errado, sai tudo trocado, sai tudo coxo, etc. As pessoas gostam muito porque isso é precisamente o sinal do génio, mas o pior é o que acontece aos génios. Eu lembro sempre aquela 
frase famosa do Fernando Pessoa que dizia assim: Em Portugal os poetas produzem como Deus é servido, e Deus fica mal servido. E precisamente significa esse grave problema para que Fernando Pessoa já chamava a atenção há várias décadas. Aliás, não só Fernando Pessoa. [...] Se nós lermos a Literatura Portuguesa desde os primórdios dela, [...] escrita numa língua chamada Galaico-Português [...], desde esse tempo nós assistimos [...] a numerosas queixas dos escritores a esse respeito. Os escritores todos se queixam, em Portugal, de que as pessoas não entendem o que eles escrevem [...]. É o caso de Camões a protestar que quem não sabe arte não a estima. [...] Ou então os escritores, quando são muito inteligentes, fazem o jogo contrário. E há um grande escritor português, talvez um dos melhores prosadores que Portugal jamais teve, um dos melhores escritores do mundo no século XVI, que é Fernão Mendes Pinto, o famoso autor da Peregrinação, que se jogou na carta contrária, e, se percebeu onde estava, percebeu com quem lidava, e escreveu um livro a fazer-se parvo, a dizer que ele, coitado, não sabia escrever, ele não percebia nada do que ele estava a dizer, ele era um pobre triste que não conhecia coisa nenhuma, e apenas falava das suas experiências, das suas coisas. E por estar inocente disse tudo quanto quis, não é? E ninguém percebeu [...] porque partiram do princípio de que ele, coitado, era um analfabeto que não sabia o que dizia.

MT - Jorge de Sena está em Moçambique e vai efectuar diversas conferências sobre Luís de Camões e Os Lusíadas. [...] Verificamos uma utilização d'Os Lusíadas e de Luís de Camões (uma utilização simbólica) que poderia servir, no seu próprio tempo, como uma determinada ideologia, uma determinada doutrina politica, e determinadas intenções políticas, e que são, transplantados esses mesmos símbolos, para uma utilização atual. Portanto, deixando de lado esse valor simbólico d'Os Lusíadas que poderá estar certo ou poderá estar errado, [...] qual é, de facto, a importância de Luís de Camões e d'Os Lusíadas para a nossa época?

JS - Bem, [...] eu tenho a experiência de ser professor no estrangeiro e não em Portugal... Quer dizer que eu, quando estou a ensinar a Literatura Portuguesa, [...] eu estou a ensinar [...] a pessoas que não estão a estudar a literatura que seja a literatura deles, embora eu deva dizer, e acentuar, que os brasileiros, tal como os norte-americanos, não consideram que a Literatura Portuguesa anterior aos princípios do século XIX não seja deles, da mesma forma que na América ninguém pensa que Shakespeare não seja americano, na medida em que é a literatura do passado comum da língua e do passado comum do país. Antes de 1822 o Brasil estava a formar-se e a nascer, mas não era o Brasil, era parte de Portugal. Portanto, o preço que nós hoje pagamos disso é que a Literatura Portuguesa até essa data lhes pertence a eles também, da mesma forma que os norte-americanos acham que a Literatura Inglesa até a separação, até aos fins do século XVIII, lhes é 
comum, inteiramente comum, e que não é mais propriedade da Inglaterra do que é deles. E, de certo modo, essa posição é correcta. Mas, por outro lado, não têm o mesmo comprometimento, digamos, de tradição cultural e ideológica, em relação a esses autores. Quer dizer: para Portugal, Os Lusíadas podem ser representados como a glorificação do Império, das glórias nacionais, etc. Isso no Brasil não interessa tanto. $\mathrm{O}$ que não impede que Camões seja considerado como o maior poeta da Língua Portuguesa e o maior escritor da Língua Portuguesa tal qual como em Portugal. Simplesmente as razões não são exactamente as mesmas. $\mathrm{O}$ que mostra que uma coisa não está necessariamente ligada à outra. Se agora mudarmos para os Estados Unidos, ou [...] qualquer outro país que não seja de língua portuguesa, em que Camões, portanto, não aparece como a figura máxima de uma língua (que é nossa), mas como a figura máxima de uma literatura estrangeira que a gente diz que é importante (e que aquele sujeito é o mais importante de todos), nessa altura nós temos de defender Camões, não em termos das nossas tradições culturais, mas em termos do próprio valor literário, porque as nossas tradições culturais só podem interessar ao estudante de Língua Portuguesa nos Estados Unidos na medida em que ele quer conhecer a Cultura Portuguesa e a Cultura Brasileira, e compreendê-las. Mas isso não quer dizer que ele compra aquilo que nós engulimos há 400 anos. Não tem nada que ver uma coisa com a outra. [...] Quando Os Lusíadas foram publicados, em 1572, o Camões estava já, como se sente n'Os Lusíadas, muito aflito, e com muitas dúvidas em relação ao que iria acontecer àquilo tudo. E vimos, em 1580, o que é que aconteceu. [...] Houve um desastre nacional no Norte de África, de proporções gigantescas, mais gigantescas do que realmente se pensa, se nós pensarmos que toda a grande administração, toda a grande nobreza - e eu costumo acentuar: até os capitães donatários do Brasil - todos se embarcaram para morrer em Alcácer-Quibir ao lado do Rei. De um dia para o outro, a nação se viu decapitada de milhares de pessoas que eram toda a administração, eram as cabeças de todas as famílias, era o país inteiro, por toda a parte. No entanto, $[. .$.$] as esquadras que estavam em todos os$ mares, nenhuma delas se deslocou para transportar o Rei a Alcácer-Quibir. A esquadra que o transportou a Alcácer-Quibir foi outra. Quer dizer que tinha um império chamado Império e ficou onde estava. [...] De 1580 a 1640, quando a união das duas Coroas se dá - e isso é uma coisa que ainda hoje é difícil a muitos portugueses olharem sem complexo - é preciso nós termos presente que, mesmo no fim do século XVI, [...] Portugal era um dos países que maior nacionalismo tinha desenvolvido. A Literatura do século XVI demonstra isso claramente. No entanto, era perfeitamente normal, dentro das estruturas políticas da Europa (e quem diz da Europa diz da Ásia), que os reinos mudassem de mão. E, até certo ponto, as pessoas não se consideravam menos nacionais de um reino, até certo ponto, evidentemente... pelo menos as grandes oligarquias não consideravam, se o rei fosse um estrangeiro qualquer. Eles continuavam a ser o que eram e o rei era um 
outro sujeito do outro lado. E isto foi salvaguardado, até certo ponto, em Portugal, em 1580, porque Felipe II de Espanha era um homem inteligente, ao contrário do que a lenda negra [dele] tem feito; e, além do mais, era um homem que amava Portugal profundamente. [...] Um homem que era 16 vezes descendente de D. João I era mais português que muitos portugueses [...]. Na união das duas Coroas, $[. .$.$] os portugueses conservam o governo de Portugal e o governo$ de todo o seu Império para o qual os espanhóis não podem ser nomeados. Mas, em compensação, como súbditos de Sua Majestade, podem ser nomeados para todos os postos na Espanha, e na verdade foram membros do Conselho de Estado em Madrid e governaram a Espanha, durante esse período, muitos deles o que, temos que concordar, para aquelas altas aristocracias era uma posição altamente invejável, que de certo modo explica o comportamento que elas tiveram em 1580. 1580, ao mesmo tempo em que era um desastre nacional, para as grandes oligarquias portuguesas foi uma promoção colossal: elas passaram a governar o Império Espanhol, que era uma coisa gigantesca, juntamente com o Português. Era realmente o mundo inteiro. E repare-se que, quando Felipe II une o Império Português com o Império Espanhol (a gente tem que pensar que a pobre da França e a pobre da Inglaterra ficaram assim duas ilhas no meio daquilo tudo...) não havia mais nada que não lhe pertencesse. Visto que [...] o Felipe II [...] reinava em Nápoles, reinava em Milão, reinava na Flandres, reinava no que é parte da Borgonha, reinava na Espanha toda, reinava em Portugal, o que quer dizer que reinava também desde o México até à Patagónia. E na Índia, e nas Filipinas, em toda parte! Por outro lado, Os Lusíadas, nesse contexto, de 1580 a 1640, representaram, de certo modo, a continuação desse ideal nacionalista que vinha do século XVI. Quando, em 1640, a separação se dá [...], (com a famosa Revolução de 1. ${ }^{\circ}$ de Dezembro, que foi curiosamente um putsch lisboeta exactamente como a revolução de 1383 tinha sido, e tal como em 1580 falhou ao Prior do Crato, ao Rei D. António) as idéias literárias, etc. tinham variado muito. E se ele continuava a ser o grande poema nacional, a verdade é que as modas literárias já não coincidiam com o gosto do século XVI, e isso acentua-se mais com o andar do tempo. No entanto, os chamados classicistas do século XVIII, aqueles que a gente costuma chamar «árcades» (o que é um nome que dá uma grande confusão porque uns eram e outros não eram, e Arcádias houve mais que uma), esses homens tiveram por Camões uma consideração enorme. Eles consideraram que Camões era o grande clássico da língua, que era preciso «reverter» para limpar a Literatura Portuguesa daquilo que eles consideravam influência espanhola. E quando vem o Romantismo, [...] o Camões desempenha nessa altura um papel curiosíssimo: se para Portugal ele é o símbolo daqueles nacionalismos do século XVI (e o Romantismo era muito nacionalista, como se sabe), por outro lado é também, para o resto da Europa [...], o mito do poeta incompreendido e desprezado pela sociedade e infeliz no amor. E foi isso, em grande parte, aquilo que interessou à 
Europa, [...] visto que, lembrem-se, nos princípios do século XIX o resto da Europa não estava interessado nas glórias portuguesas no Oriente. [...] É quando a lenda e a utilização de Camões num sentido político começa. Começa precisamente, e estranhamente, com os positivistas republicanos em 1880, no "Centenário», chamado, «da Morte de Camões», que é quando se fazem as grandes celebrações camonianas [...], que tiveram pelo menos uma grande vantagem: [...] desencadearam uma vaga de estudos e de revisão crítica de que partiu realmente a primeira revisão crítica de que Camões necessitava. [...] Desde o fim do século XVI até o fim do século XIX a obra de Camões tinha aumentado, em número de obras, do dobro ou do triplo. E não há poeta nenhum, português ou espanhol, desde os meados do século XVI, antes de Camões nascer, até aos meados do século XVII, muitas décadas depois de Camões ter morrido, que não tenha contribuído para a obra camoniana. Estão lá todos. É claro que era preciso fazer um trabalho crítico de limpeza. Não porque as obras fossem más, mas apenas porque não eram dele, eram de outras pessoas, já estavam publicadas em nome dos outros. Este trabalho [...] começou logo na primeira edição das Líricas de Camões. Quando, postumanente, a primeira edição das Líricas de Camões apareceu, elas incluíam dois poemas de Garcia de Resende impressos no Cancioneiro Geral em 1516, antes do Camões ter nascido, o que, francamente, é atribuir muito ao génio do Camões! Que o Camões tenha colaborado no Cancioneiro Geral em nome de Garcia de Resende antes de nascer, é impossível! E isto aconteceu com numerosos outros. O Garcilaso de la Vega está lá, o Sá de Miranda está lá, o Boscán está lá, o Hernando da Cunha está lá. Não há poeta espanhol daquele tempo que não esteja lá. [...] É um trabalho que nós temos de fazer duplo. Primeiro, $[. .$.$] tirar das obras de Camões coisas que não são dele, ou que são$ suspeitas e que ainda continuam lá, ou pelo menos indicar a que ponto elas são suspeitas. E por outro, incluir na obra de Camões diversas coisas que os editores contemporâneos de Camões continuam a ignorar, e que estão em numerosos manuscritos atribuídos a ele, e que não temos razão nenhuma para duvidar que possam ou não ser dele, porque são dele ao mesmo título que é o de outras peças que foram primeiro publicadas em nome dele e que não têm garantia nenhuma senão essa. Ora, se eu posso acreditar que um poema é de Camões por estar impresso na primeira edição, por que é que eu não hei de acreditar que um poema é de Camões porque aparece o nome dele num manuscrito do século XVI? Não há razão nenhuma para duvidar. É ter muita fé, demasiada, na letra impressa e muito pouca na letra manuscrita. Me parece que é base de toda a investigação erudita acerca da autoria de autores antigos. Nós não temos [...] nenhum manuscrito de Camões. Nenhum. E nem os primeiros editores de Camões disseram que eles os tinham visto. Todos eles disseram que tinham visto apenas cópias. Mas isto também não deve desconsolar as pessoas. Nós também não temos manuscritos poéticos do Shakespeare. [...] Os textos de Shakeapeare que vocês lêem 
correntemente são um cozinhado que os eruditos fizeram sobre as diversas relações que existem de algumas das peças. E há brigas enormes entre os eruditos shakespearianos para saber se se pode usar este verso e não usar aquele [...]. As pessoas julgam que esse desastre só aconteceu ao Camões. Esse desastre aconteceu a toda a gente. Eu conto uma anedota muito divertida, para vocês saberem a que ponto se deve ter cuidado com os escritores [...], uma anedota que aconteceu em Harvard, of all places, como diriam os ingleses, com um escritor norte-americano que se transformou em inglês, e quando se transformou em inglês se tornou mais inglês que os próprios ingleses, que até é T. S. Eliot. [...] Eliot aparece íntegro em todas as histórias e antologias de Literatura Norte-americana como um escritor norte-americano, e, da mesma forma, aparece nas histórias e nas antologias da Literatura Inglesa como um escritor inglês, até porque [...] entre a Inglaterra e a América não existem aquelas patacoadas que existem entre Portugal e o Brasil, em que, em Portugal, não se põem os escritores brasileiros nas selectas que é para as pessoas não se contaminarem daquela gramátiva horrível. $\mathrm{E}$ no Brasil não se põem os escritores portugueses para que não se pense que os escritores portugueses estão a colonizar o Brasil outra vez, o que é, evidentemente, uma situação mutuamente ridícula. Entre a América e a Inglaterra isso não há. Uma antologia da English Poetry inclui, em termos linguísticos, os poetas norte-americanos e os poetas ingleses lado a lado, e ninguém se importa com os anglicismos da América ou com os americanismos da Inglaterra. Isso está abaixo da Literatura. Isso são ocupações de gramáticos desocupados, não são ocupações de escritores, nem são ocupações dos povos cultos. [...] É que há uma coisa chamada Linguística que mostra que as línguas nunca estão certas nem erradas. Eu não posso dizer que qualquer povo fale certo ou errado [...]. O que eu posso dizer é que há uma língua padrão, mais ou menos, que se estabeleceu artificialmente, e que essa língua não coincide com aquela que está viva na boca do povo. [...] Os «Camões» todos souberam isso perfeitamente. E por isso mesmo é que eles foram capazes de escrever em tão variados níveis de linguagem como escrevem. [...] O nível de linguagem d'Os Lusíadas não é o nível das canções, não é o nível dos sonetos, não é o nível das redondilhas, e não é com certeza o das cartas em prosa. $\mathrm{E}$, no entanto, tudo isso foi escrito pelo mesmo homem. Apenas esse homem sabia muito bem que os níveis de linguagens variavam conforme aquilo que ele estava a fazer. [...] As pessoas, por exemplo, pensam que a Língua Portuguesa é assim uma coisa como a Italiana ou como o Alemão. [...] Na Itália, as pessoas entendem-se umas com as outras porque falam uma língua artificial e culta, criada pela Literatura, com Dante e com Bocaccio [...]. É uma língua da cultura que unifica a Itália, mas não é a língua que nenhum napolitano ou nenhum veneziano fala. [...] A Alemanha, a mesma coisa. [...] Toda a Alemanha é dialectal. [...] Até certo ponto, e ao contrário do que se julga, é exactamente o que sucede na França. [...] Nós é que estamos mal habituados, e temos muita sorte, porque, 
realmente, com todas as diferenças linguísticas que nós possuímos, nem Portugal nem o Brasil têm entre si, ou dentro de si, tamanhas diferenças linguísticas como estes países todos têm. E as diferenças entre Portugal e o Brasil são muito menores do que as diferenças existentes entre o Norte e o Sul da Alemanha, ou [...] da Itália [...].

\section{MT - Nós queríamos pedir a Jorge de Sena que continuasse aquela história...}

JS - ... do Eliot! [...], para celebrar o acontecimento que culminaria, depois da primeira conferência do Eliot, com um jantar em que aqueles ilustres sujeitos estariam todos presentes para homenagear o Eliot... [...] Eu nunca conheci na minha vida uma pessoa mais solene, mais engravatada, mais encolarinhada, mais empertigada do que o Eliot, coitado. Ele devia sofrer por dentro imensamente com aquilo, mas ele tinha vestido aquela capa de empregado de banco da city, e foi uma capa que ele nunca conseguiu despir a vida inteira, ficou para a vida inteira assim, ficou encolarinhado, engravatado, penteado até ao fim da vida... [...] O professor lembrou-se de fazer um programazinho para o jantar, em que ele imprimia um dos poemas famosos do Eliot. Para isso, como era um homem cuidadoso, foi procurar uma edição dos poemas e copiou. Depois, lembrou-se de ver noutras edições como é que o poema estava. E ele viu que o poema tinha variante de edição para edição. Quer dizer que o Eliot tinha feito nas provas, em certas edições, emendas [...]. Ele então fez uma versão em que ele misturou várias dessas emendas, que não correspondem todas ao mesmo estado de uma edição, e imprimiu isso no poema. Depois houve a conferência, houve o banquete, e, no fim do banquete [...] ele pediu ao Eliot para verificar se o poema estava certo, porque ele tinha a impressão que havia coisas que não estavam, que não tinham ficado bem. E o Eliot olhou com muita atenção, leu muito concentradamente, e fez uma série de emendas no texto. Nenhuma delas era nenhuma das emendas que ele tinha feito nas diferentes edições; quer dizer: ele tinha emendado o poema outra vez!

MT - [...] Recordo-me de ter lido no prefácio escrito por Jorge de Sena às obras completas de António Gedeão que, muito possivelmente, muitas pessoas entre nós, se admirariam da forma como criticava, ou fazia a crítica da poesia de António Gedeão, como de qualquer outra poesia que criticasse, através inclusivamente de uma forma matemática, aplicando, portanto, a própria matemática ao estudo da estrutura da poesia, da estrutura de uma obra. Por que razão é que Jorge de Sena sugere que as pessoas se admirem, em Portugal, desse tipo de crítica?

JS - [...] É que eu estou convencido de que muitas pessoas que em Portugal estudam Letras não é porque tenham queda nenhuma especial para Letras, é porque têm um medo danado da Matemática e reprovaram nela. Mas isso, a 
culpa não é minha, a culpa é dos maus professores que elas tiveram, não é? Isto para começar. Por outro lado, eu penso [...] que hoje a quantificação de todos os estudos em Ciências Humanas é um caminho natural de toda e qualquer crítica. É possível que a gente chegue, ao fim de tanta quantificação, a certos resultados que certos génios da crítica intuíram, mas com uma diferença: é que a gente chega a eles comprovadamente, ao passo que os génios da crítica intuiram e não há prova nenhuma de que eles estejam certos até que provem o contrário. E é por isso que a crítica é sempre uma briga entre comadres, [...] porque ninguém tem provas daquilo que está a dizer [...]. Ora, o que é preciso fazer na Crítica Literária é exactamente o mesmo que os homens da Ciência do Direito sabem: há coisas que são matéria de direito, outras que são matéria de facto, outras que são matéria de opinião. [...] O que se pretende é apenas separar o que é matéria de direito, o que é matéria de facto, o que é matéria de opinião, porque evidentemente opinião sempre haverá. No fim de estudar tudo quanto eu quiser, eu posso sempre achar que um sujeito não presta. E da mesma forma eu posso fazer o contrário. Eu posso contar uma história engraçadíssima que se passou com um grande crítico que eu estimo muitíssimo e que considero um dos melhores que existem em Portugal, e perdoar-me-ão de não citar o nome porque a história não é inteiramente agradável. Ele foi convidado a escrever uma vez, para uma magna publicação coletiva, um artigo sobre um poeta extremamente secundário do século XIX. Aliás, já o convite envolvia uma certa perfídia porque, evidentemente, os escritores de primeira plana tinham sido dados a críticos medíocres, e a um crítico da categoria dele foi dado um escritor medíocre. Ele vingou-se do convite fazendo um estudo monumental, que situava esse escritor, do ponto de vista sociológico, cultural, histórico etc., duma maneira extraordinária, e que iluminava, perfeitamente, como é que aquela poesia e como é que aquele homem podiam ter existido. E uma vez estava a conversar com ele e ele perguntou-me: «o que é que tu achaste do meu artigo", e eu disse: «bem, eu acho o artigo maravilhoso, eu acho uma coisa extraordinária, a única coisa que tu esqueceste de dizer é que ele não presta».

MT - Falando agora da estadia de Jorge de Sena entre nós, aqui em Moçambique. Qual o plano das conferências que vai fazer?

JS - [...] Eu não quero, de maneira nenhuma, fazer num ano aquilo que outros têm feito na vida inteira, que é ser caixeiro-viajante do Camões, Deus me livre. Mas realmente, eu este ano transformei-me, por força das circunstâncias, numa espécie de caixeiro-viajante do Camões. [...] Falei dele em Paris, [...] Londres, [...] Bruxelas, [...] Connecticut, [...] Texas [...], falei nas celebrações da Universidade da Califórnia, [...] corri daí para San Diego, onde se fazia o Simpósio do Renascimento, [...] depois para San Francisco [...], e no fim disto tudo, meia dúzia de dias depois da última corrida, eis que atravesso meio mundo 
para vir falar do Camões aqui. De modo que isto já começa a me parecer demais. Eu começo a pensar que, acabado este ano, publicado este livro que eu tenho sobre Camões, eu vou descansar dois anos. Ou, pronto, eu vou deixar o Camões em repouso dois anos. É o mínimo dever da minha pessoa: é deixá-lo em paz, que é uma coisa que as outras pessoas não têm feito. Mas, [...] a possibilidade que me foi dada por amigos daqui, da Associação dos Antigos Estudantes de Coimbra, [...] é tanto mais generosa quanto eu nunca fui estudante de Coimbra. [...] Mas eu não venho aqui só para falar de Camões. Eu venho aqui sobretudo para ouvir [...]. Eu quero conhecer a vida cultural de Moçambique [...]. E quero sobretudo, que é o que me fascina mais, ver a Ilha de Moçambique, para onde parto amanhã porque [...] é um dos raros lugares onde nós temos a certeza de que Camões esteve, porque temos, digamos, certa documentação escrita disso mesmo. O resto, a gente deduz que ele esteve em milhentas partes, mas não temos a certeza autêntica e documentada de nenhuma. Daquele lugar temos, assim como temos que ele depois foi para Lisboa e publicou Os Lusíadas. [...] E de Camões, biograficamente, nós não sabemos praticamente nada. Uma das coisas que nós sabemos é que ele esteve na Ilha de Moçambique [...] não no sentido glorioso, de ser recebido com bandeiras, com charangas, com foguetes, etc., não, o pobre do homem estava era encalhado lá, entalado de dívidas, sem dinheiro para ir para Portugal. E se não fosse o Diogo do Couto e outros amigos que passaram e lhe pagaram o bilhete, o homem ainda lá estava. Tinha morrido lá e não tinha publicado Os Lusíadas, porque Os Lusíadas não podiam publicar-se na Ilha de Moçambique naquele tempo [...]. De modo que eu penso que a Ilha de Moçambique tem uma grande importância histórica: é o lugar onde ele esteve encalhado, nessa altura, na viagem de regresso para Portugal, e é o lugar de onde ele se escapou para ir publicar Os Lusíadas a Lisboa. Eu acho que isto é que devia ser celebrado.

MT - [...] Sobre o panorama cultural em Moçambique, onde nós sabemos que tem mantido correspondência, ao longo de vários anos, com pessoas de Moçambique, o que dá, de certo, uma idéia sobre a vida literária, sobre aquilo que se tem, sobre aquilo que existe e que pode ser classificado como uma Literatura «de Moçambique», para uns, «em Moçambique», para outros... e gostaríamos, portanto, de pedir a sua opinião sobre essa Literatura, sobre essa vida literária.

JS - Bem, sobre a vida literária propriamente, em Moçambique, eu não posso ter assim opinião. Essas coisas só se conhecem com uma longa experiência directa. Da mesma forma não posso ter opinião, e por muito tempo não poderei ter, acerca de Moçambique em si mesma, que também essas coisas não se aprendem assim com oito dias a passear na rua e a falar com os amigos. Eu costumo dizer que eu não sou daqueles sujeitos que visitam um país, ou uma região, durante 
oito dias, e depois escrevem um livro de 600 páginas. [...] Eu não sou a Simone de Beauvoir. Essa é que tem artes de chegar a um grande país qualquer, passear para um lado e para o outro no colo de várias pessoas, e depois publicar um livro de 600 páginas. [...] Também não cresci sentado no boul' Mich' ou no Café de Flore, graças a Deus, não é? [...] Em relação àquilo que eu conheço, e colocando-me estritamente na Literatura, eu penso que todas as Literaturas estão fora, ou distantes dos grandes centros centralizadores de uma vida literária, como é o caso da Literatura Portuguesa. A Literatura Portuguesa centra-se, em parte, em Lisboa. E se as pessoas não forem assinar o ponto a Lisboa estão bem arranjadas da vida! Eu que o diga, que não vivo em Lisboa há mais de uma dúzia de anos e sei o que me custa. E, portanto, posso apreciar perfeitamente os sentimentos que possam existir nos escritores moçambicanos, porque a minha posição, de pessoa que há uma dúzia de anos não vive em Portugal, não é diferente da deles. Aquela gente, se pudesse fazer que eu não existia, faria, porque sempre fizeram isso a toda a gente. E aliás é uma velha tradição portuguesa... Já o Camões e o Fernão Mendes Pinto, essa gente toda se queixou sempre disso. Mas, por outro lado, [...] esse defeito centralizador não deve também desanimar ninguém. Eu lembro [...] o exemplo do Brasil actual. Ainda hoje, no gigantismo do Brasil, os escritores do Norte, ou do Sul, ou do interior do Oeste, que não tenham contactos literários no Rio de Janeiro, não figuram na Crítica Literária, não figuram nas Histórias Literárias e não são sequer conhecidos. Recentemente deu-se um caso quase anedótico que eu aproveito para contar. [...] Quando eu estava na Universidade de Wisconsin eu estava a dirigir diversas teses de doutoramento, umas em Literatura Portuguesa, outras em Literatura Brasileira [...]. (Sou chefe do Departamento de Literatura Comparada da Universidade da Califórnia) [...]. Uma das teses que eu estava a dirigir era sobre [...] escritores centrados no Ceará, no Norte. O meu sucessor, em Wisconsin, é um brasileiro, mas um daqueles brasileiros do Rio de Janeiro para quem aquilo que não passou pelo Rio de Janeiro não tem a mínima importância. $\mathrm{O}$ resultado é que o pobre do aluno que estava a fazer tese sob a minha direção e que agora passou para ele, viu-se numa fona, como se costuma dizer, porque aquele brasileiro do Rio de Janeiro acredita menos na Literatura do Ceará do que eu. Aqui têm vocês as contradições. E portanto, como vêem, os problemas existem, bastante semelhantes, em toda parte. Por outro lado, [...] eu penso - e talvez isto não agrade muito em Lisboa - que não há, hoje, em português, muitos poetas, mais jovens, da categoria de um Rui Knopfli. Da mesma forma que penso que não há muitos críticos em Lisboa da categoria do Eugénio Lisboa aqui. Simplesmente isso em Lisboa não se sabe e até é, digamos, herético, dizer-se, porque, por definição, todos eles, sejam de que cor forem, são todos melhores que o resto do mundo. Porque estão lá. E é só, e por mais razão alguma [...]. Foi o que aconteceu no século XVIII, quando o Brasil não era só parte de Portugal, mas a parte principal de Portugal. Os brasileiros começaram a perceber 
que se eles ficassem todos no Rio de Janeiro e em Santos não tinham saída nenhuma. Então, como eram muito ricos, todos eles começaram a pensar que, se iam estudar a Coimbra, mais engraçado era ficar em Lisboa, e eles receberiam em Lisboa as rendas que eles tinham no Brasil. E foi isso que fez com que o século XVIII, os meados do século XVIII, até os fins do século XVIII em Portugal, ao contrário do que em Portugal se diz habitualmente (e no Brasil também) - porque em Portugal isto não se sabe, e no Brasil quem sabe não diz - o que acontece é que, realmente, no fim dessa época, em Portugal, os maiores escritores portugueses são todos brasileiros, e até os ministros de Estado em Lisboa são brasileiros também. Quer dizer: eles estavam em Lisboa a governar o Império. É o caso de Alexandre de Gusmão, que assinou o famoso Tratado de Madrid, que fixa as fronteiras do Brasil com a Hispânia [...], sendo o Gusmão brasileiro de nascimento. E assim continuou a suceder durante essa época toda, com os ministros e a gente toda que rodeou D. João V, que rodeou D. José e que rodeou D. Maria I. E quando eles levaram D. João VI para o Brasil, eles não faziam mais do que levar [...] o Rei que eles já tinham no bolso. Foi exactamente o que aconteceu quando o rei se mudou para o Brasil. E precisamente por essa mesma razão foi que, quando o Rei voltou para Portugal, eles não acharam graça nenhuma que o Rei saísse do bolso. E uma vez que o Rei saía do bolso a conversa já era outra. [...] É talvez uma das razões mais profundas da Independência do Brasil em 1822. Se o Rei tivesse ficado no Rio de Janeiro, a Independência nunca se teria dado porque a capital teria mudado para lá. De modo que, como vocês vêem, essa gente do século XVIII percebeu muito bem o que é que tinha de fazer para não ser ignorada. [...] Para vocês verem as distinções de classes que se estabeleceram entre eles - por exemplo, um Basílio da Gama (o famoso autor do O Uraguai, que é um dos grandes poemas épicos do século XVIII, em qualquer língua, eu chamo a atenção), tinha uma raiva danada e um desprezo horrível do pobre do Caldas Barbosa, que era aquele sujeito que cantava lunduns e modinhas acompanhado à viola nos salóes das marquesas, em Lisboa, com um enorme êxito. E ainda por cima era mulato. E o Basílio da Gama não era. Eram ambos brasileiros. E o Basílio da Gama chamava o pobre do Caldas Barbosa "macaco", não sei quê, uma data de nomes feios, e o Caldas Barbosa respondia-lhe à letra [...]. Porque aqueles árcades todos, com aquele ar neoclássico que eles têm, é bom não ler, ou ler reservadamente, as coisas que eles se chamaram uns aos outros, e os insultos que eles imprimiram uns aos outros. [...] Muitas dessas coisas não estão sequer ainda impressas. Bem, agora começa a ser possível imprimir tudo neste mundo. E eu vou contar a esse propósito uma anedota engraçadíssima que aconteceu [...] com o eminente medievalista português Professor Rodrigues Lapa. [...] Ele era o Catedrático de Literatura Portuguesa da Universidade de Minas Gerais, em Belo Horizonte [...]. E o Rodrigues Lapa estava a preparar a edição das Cantigas de Escárnio e de Mal-dizer (como vocês sabem, nunca tinham saído 
para a mão do grande público, visto que aquele Doutor José Joaquim Nunes, que tinha publicado Cantigas de Amigo e Cantigas de Amor. [...]. coitado, não se atreveu a publicar as Cantigas de Escárnio e de Mal-dizer, seria um escândalo horrível). [...] E uma vez estava a conversar comigo e com o [...] Adolfo Casais Monteiro, e mencionou que não sabia o que havia de fazer com as Cantigas, porque [...] havia certas coisas que ele achava que o melhor era substituir por pontinhos. E nós observámos que, se ele substituísse por pontinhos o que tinha que ser substituído, por esse critério, por pontinhos, nas Cantigas de Escárnio e de Mal-dizer, ele publicava um livro só de pontinhos, não é? E por outro lado, demos-lhe o argumento máximo, dizendo assim: «Veja lá: em numerosos dos estudos filológicos dela, a D. Carolina Michaëlis publicou numerosos estudos críticos sobre essas Cantigas. O senhor que é um homem mais envergonhado que uma respeitável senhora como D. Carolina Michaëlis era...»; e o Rodrigues Lapa meditou e publicou aquilo tudo, que agora está ao alcance de toda a gente. [...] Nos meus cursos de Literatura Portuguesa, nos Estados Unidos, na Universidade, são um enorme êxito entre os estudantes, e uma das coisas que mais contribui para o triunfo e o prestígio da Literatura Portuguesa; são precisamente as Cantigas mais pornográficas as que os meus estudantes mais apreciam. De modo que, como vêem, até a pornografia contribui para o prestígio de Portugal.

MT - Uma última pergunta, que nós fazemos, de certa maneira, por curiosidade. Existem idéias generalizadas entre nós de que, nos Estados Unidos da América, há uma grande falta de Cultura Humanística. O Jorge de Sena, como professor de uma Universidade Americana, na Califórnia, poderá dizer-nos se isso é verdade, e como funciona a Universidade Americana.

JS - [...] Ao falarmos de Cultura Humanística e de Universidade nós temos que falar das duas em saparado e das duas juntas, porque não é tudo a mesma coisa. Eu acho que essa idéia de que na América falta uma Cultura Humanística é, em grande parte, uma presunção européia, porque eu pergunto: qual é a Cultura Humanística da maior parte das pessoas em qualquer parte? [...] Por exemplo, em Portugal, ou na Espanha, ou na França, lambuzam-se de três páginas literárias de jornal e julgam-se humanistas, e os americanos são mais modestos. Antes de terem lido as obras, antes de terem lido as críticas, antes de terem estudado vários anos, eles não acham que sabem as coisas. Isto é uma diferença bastante importante. Em segundo lugar, é um facto que, se passamos agora para os altos níveis culturais, os americanos têm a mania da especialização. E a especialização, dentro do gigantismo das universidades norte-americanas, tornou-se, até certo ponto, uma indústria [...]. A grande habilidade está em um sujeito se tornar especialista de uma coisa que ninguém sabe o que é, porque, como ninguém sabe o que é, fica o especialista extremamente prestigioso, e ninguém sabe dizer se 
aquilo que ele escreve presta ou não presta [...]. Eu encontrei uma vez um senhor, com um grande pasmo meu, que estava a discutir comigo de Literaturas Hispano-Americanas, que são literaturas que me interessam muitíssimo, e cuja leitura eu recomendo às pessoas, sobretudo as contemporâneas, visto que eu acho que mais vale ler certos romancistas mexicanos, chilenos, colombianos, argentinos de hoje, do que passar a vida a ler o Nouveau Roman que, segundo a minha teoria, é o último produto francês inventado, de exportação, para o consumo nos Departamentos de Francês dos Estados Unidos. É o que o Nouveau Roman, em grande parte, me parece, independentemente do interesse que possa ter como experiência. Uma coisa é a experiência, outra coisa é o valor das obras que a gente não consegue ler sem sacrifício além da página 50 , porque são uma chatice de todo tamanho, [...]. De toda essa gente do Nouveau Roman, os melhores de todos são os que são menos Nouveau Roman, como a Marguerite Duras ou o Claude Simon. Os outros são todos uns chatos que têm, é claro, atrás de si, o prestígio da França, e como toda a gente acha que a França é uma cultura gigantesca (e de facto é, mas é sobretudo uma cultura que sabe vender-se aos outros admiravelmente), toda a gente cai de cócoras, porque, tudo o que é aclamado em Paris, as pessoas caem de cócoras primeiro e admiram depois. Mas, voltando ao ponto em que estávamos, [...] eu tinha feito uma conferência [...], que comparava a Literatura Brasileira com as Literaturas Hispano-Americanas. E eu criei um grande escândalo entre os profissionais do hispanismo latino-americano quando eu disse $[. .$.$] que [. .$.$] a única comparação possível para se poderem colocar as$ coisas no devido plano era considerar que as literaturas dos diversos países hispano-americanos correspondiam às literaturas estaduais do Brasil. Quer dizer que nós poderíamos falar de [...] Literatura do Rio Grande do Sul, Literatura do Rio de Janeiro, Literatura de São Paulo, ao mesmo título em que falávamos de Literatura Peruana, Colombiana, Chilena, etc. O que não se aplica, de certo modo (devemos ser justos), à Argentina, ao Chile ou ao México, que são aqueles que têm uma massa de criação literária que constitui já, pode dizer-se, uma Literatura. Mas a maior parte dos outros não. E até porque são muito pequeninos, os países. Então eu encontrei este fenómeno extraordinário: o homem começou a discutir comigo e a certa altura eu disse: «Ah, eu vejo que o senhor é especialista em Literatura Hispano-Americana», e ele disse «Não». Ficou indignadíssimo. E então eu disse: "Ah não, mas parece-me que sim...", «Não, não, mas eu não sou. Eu sou especialista do Romance da Nicarágua». E eu olhei para ele, deu-me uma fúria - e isto era em público, no debate no fim da conferência - deu-me uma fúria e eu disse: «Pois dou-lhe os meus parabéns, porque o senhor consegue ser especialista de uma coisa em que, na Nicarágua, toda a gente teria vergonha de ser especialista, porque as pessoas na Nicarágua vivem todas ansiosas de viver na Nicarágua, e a ler os outros, dos outros países, e o senhor é o único que os lê todos.» Isto dá a idéia do que pode ser a intrugice da especialização. Eu conheço, 
por exemplo, um professor, na América - que é americano, aliás - que dá, todos os anos, um seminário anual sobre o conto peruano. Eu não tenho nada contra a Literatura do Peru, acho muito respeitável. Nem contra o conto peruano. Mas acho que uma pessoa passar um ano inteiro a ler contos peruanos e a discuti-los em aula como se fossem a Divina Comédia é um bocado de exagero, não é? Bem, estas coisas acontecem. Mas estas coisas não são realmente a imagem que nós devemos tomar da universidade norte-americana. Se assim fosse, será que nós, por exemplo, se pegássemos em certas universidades européias, não podíamos criar imagens igualmente abomináveis e ridículas? Será que não há medíocres em toda parte do mundo? Evidentemente que há. Há em todas as universidades sujeitos que há 15 anos lêem a mesma sebenta a toda a gente. Quando eu me formei em Engenharia na Universidade do Porto, [...] havia um professor que era professor de Teoria Geral de Máquinas, e isto passava-se nos anos 40. Pois bem, essa Teoria Geral de Máquinas acabava antes dos motores de explosão. E nós éramos obrigados a saber de cor e a desenhar no quadro os esquemas de todos os modelos de caldeiras vigentes no fim do século XIX, nenhuma das quais já tinha qualquer utilização no mundo daquele tempo. Mas estava na sebenta. E uma das perguntas sacramentais que havia no exame era: "Quais são as tendências modernas na construção de caldeiras?», que nós todos tínhamos de responder pelo catecismo, estava publicado na sebenta, eram vinte características que nós tínhamos todos de dizer, as vinte, pela ordem que estavam escritas na sebenta, e correspondiam ao estudo científico das caldeiras exibidas na Exposição Universal de 1900! De modo que aqui têm vocês um exemplo concreto de que disparates desta ordem podem acontecer em toda parte e em universidades extremamente respeitáveis, [...] onde podem haver grandes professores, e onde, ao lado dos grandes professores, existem esses sujeitos. Isto acontece em toda parte do mundo, não julguem que é privilégio nosso. [...] $\mathrm{Na}$ visão geral da Cultura Norte-Americana, a Cultura, no sentido em que nós a entendemos, não tem propriamente, ou não tinha, até recentemente, um papel público, porque existia o mito do self-made man, e o self-made man era o homem que não tinha estudado nada, tinha começado por vender jornal na rua, depois tinha varrido as ruas, depois tinha passado a limpar as montras, depois tinha passado a limpar o balcão, e depois do balcão, tinha casado com a filha do patrão, e enfim, aquele romance que a gente conhece e que ainda hoje serve de base para as estruturas dos romances cor-de-rosa que as meninas lêem, [...] e fazia parte do mito norte-americano. Esse mito, hoje, já está guardado na gaveta e é só para exportação. $\mathrm{Na}$ América, a maior parte das pessoas já não acredita nisso. [...] Agora, outro ponto que eu queria acentuar é que, para além dessa visão geral, que não é favorável à Cultura, e que, mais do que isso, chegou a criar o mito de que uma Cultura Literária era um sintoma de efeminamento, e isto fazia parte do mito norte-americano, quando nós hoje todos sabemos, por estudos sociológicos, psicológicos, etc., ao contrário do que se julgava 
dantes, que os centros maiores de efeminamento são os grandes ginásios, os grandes estádios, etc., onde todos aqueles atletas, todos, às vezes, são mais efeminados, por dentro, do que muitos outros o são por fora. [...] A verdade é que hoje a Cultura ocupa um papel fundamental na vida dos Estados Unidos. [...] Os Estados Unidos possuem duas mil e quinhentas universidades. [...] Eu, para ser catedrático efectivo da Universidade da Califórnia, não preciso ser cidadão norte-americano [...]. E este é um dos raros países do mundo onde tal coisa acontece. Mas quando se organizar, como parece que se vai organizar, uma união de todas as associações de professores que incluirá os professores primários, os secundários e os universitários, na América... Vocês sabem quantas pessoas são? Três milhões. Se vocês a isto acrescentarem os estudantes... [...] Isto vos dá uma idéia do gigantismo colossal do que seja o ensino universitário na América. E esta é a grande revolução social que está a acontecer nos Estados Unidos. Por outro lado, como se está vendo, e eu, como residente estrangeiro, não me cumpre discutir a política interna de um país onde vivo [...]. Os museus da América são dos mais ricos do mundo. O Metropolitan de New York, o Art Institute de Chicago, mas mesmo o Museu de Boston, de Cleveland, de Pittsburgh, de Saint Louis, de Los Angeles, de San Francisco, etc. têm das maiores coleções de arte do mundo. Se uma pessoa quiser estudar os impressionistas franceses tem de ir a Boston. Se uma pessoa quiser estudar o começo da Arte Moderna neste mundo, uma pessoa tem de ir a New York e a Chicago, onde estão todas as obras, ou quase todas as obras principais da Arte Moderna. As Deimoselles D’Avignon e a Guernica, de Picasso, estão ambas no Museu de Arte Moderna de New York. E os famosos quadros de Kandinsky que iniciaram a Arte Abstracta, os do Delaunay, da decomposição da Torre Eiffel, etc., estão no Art Institute de Chicago. Isto vos dá uma idéia. Por outro lado, esses museus não são aquelas coisas funéreas e desertas a que a nossa cultura está habituada tristemente. São uma coisa cheia de gente a todas a horas de todos os dias. E mais do que isso: todas as turmas das escolas primárias e secundárias, todas elas visitam, periodicamente, e em visitas acompanhadas, os museus mais próximos. [...] Todos os meus filhos, em todos os graus das escolas em que estiveram, foram, todos os anos, e às vezes mais do que um ano, levados a Chicago numa excursão que custava cinco dólares por cabeça, a qual incluía [...] visitar o Art Institute, [...] almoçar, [...] assistir a um concerto da Orquestra Sinfónica de Chicago, e várias vezes eles ouviram, por exemplo, o Menuhin, ou o Rostropovich, e depois iam jantar a correr e à noite iam ao espetáculo principal de teatro que existisse em Chicago, e voltavam às duas horas da manhã. Isto acontecia sistematicamente. Isto é feito a todas as crianças, obrigatoriamente quase, porque toda a gente se sente, de certo modo, forçado a permitir que o filho vá, e vocês hão de concordar que, em dez anos, alguma coisa fica. Portanto, eu insisto que isto não é ser filo-americano, nem pró-americano, que a América não precisa de mim, nem para defender nem para atacar. É apenas chamar 
a atenção para certos mitos que existem, para certas realidades que existem. Às vezes, há pessoas que me perguntam, e deixe-me dizer isto já para dar um outro dado: há pessoas, com o ar mais idiota do mundo, que me dizem assim: «Mas como é que o senhor consegue viver na América? É uma coisa horrível, tem coisas medonhas», e eu digo: «Pois tem, mas se há muitas coisas de que eu não gosto eu posso pensar, por exemplo, que $40 \%$ dos americanos também não gostam, de modo que, se eles se sentem extremamente incomodados, eu tenho menos direito de sentir-me incomodado do que eles, porque eu sou hóspede, e eles são da casa.»

MT - Professor Jorge de Sena, nós queríamos agradecer o tempo que nos dispensou para esta entrevista e desejar que realmente venha a encontrar em Moçambique tudo aquilo que realmente procura, sem desejar que as conferências sejam, de facto, um êxito porque não vale a pena desejar, se serão de facto.

JS - Bem, é sempre bom desejar. [...] Eu sou um sujeito extremamente supersticioso [...]. Eu vou-lhe contar uma história, só para terminar: a minha avó materna era uma senhora, que aliás teve em Angola papel mais ou menos histórico. [...] E os nativos chamavam em Angola à minha avó a «senhora grande», e ela era conhecida em Angola por esse nome, o que significa alguma coisa. Essa senhora [...] vinha daqueles tempos do Liberalismo, em que as pessoas eram muito cépticas, muito irónicas acerca de tudo, e todos nós, directa ou indirectamente [...]. A minha avó era uma pessoa muito nimiamente religiosa. [...] Quando começou a chegar ao fim da vida, começou a encher o quarto dela de retratos de santos, com lamparina, etc. E um dia eu entrei lá e disse: «Mas ó avó...» [...] Minha avó olhou para mim com aquele ar irónico e superior que ela tinha e disse assim: «Pois é, meu filho, mas quando se chega à minha idade não custa nada tomar algumas precauções.» De modo que eu penso que, quando a gente não tiver alguma fé, ao menos toma algumas precauções porque, nunca se sabe... e não temos a certeza de coisa nenhuma. É aliás o sentido de um soneto que eu publiquei uma vez, e que encerra o meu livro Fidelidade, e que é dedicado à memória do Papa Pio XII [...], principalmente por se dizer, e isto tem sido notícia, que quando ele estava a morrer quis ouvir o Allegretto da Sétima Sinfonia de Beethoven, o que pelo menos mostra que era um homem de muito bom gosto. E uma pessoa querer morrer ao som dessa música é realmente alguma coisa. E esse soneto tem como primeiro verso e último verso este, de um homem que é agnóstico, como eu: Como de vós, meu Deus, me fio em tudo. E eu acho que esta é que é a posição que a gente deve assumir. Tanto faz que Deus exista como não exista, tanto faz que ele se interesse por nós como não interesse, que a gente o venere ou não venere, de uma maneira ou de outra o melhor é a gente fiar-se... 
«Quem muito viu...» ${ }^{4}$

Quem muito viu, sofreu, passou trabalhos, mágoas, humilhações, tristes esperanças;

e foi traído, e foi roubado, e foi privado em extremo da justiça justa;

e andou terras e gentes, conheceu os mundos e submundos; e viveu dentro de si o amor de ter criado; quem tudo leu e amou, quem tudo foi.

não sabe nada, nem triunfar lhe cabe em sorte como a todos os que vivem. Apenas não viver lhe dava tudo.

Inquieto e franco, altivo e carinhoso, será sempre sem pátria. E a própria morte, quando o buscar, há-de encontrá-lo morto.

${ }^{1}$ A quem agradeço imensamente ter-me proposto a transcrição e ter autorizado esta publicação. ${ }^{2}$ Agradeço também à Professora Doutora Gilda Santos, pelo apoio e orientação no vasculhar do espólio de Jorge de Sena.

${ }^{3}$ À qual agradeço não só esta, mas anterior bolsa de pesquisa, gerida pela Cátedra Jorge de Sena (2003-2004).

${ }^{4}$ Poema de Peregrinatio ad Loca Infecta (Lisboa: Portugália Editora, 1969), lido ao fim da entrevista, com uma alteração no segundo verso: foi lido «esperanças» no lugar onde se publicou «surpresas», o que pode ter sido apenas lapso. 